doi:10.5937/SelSem1602011M

\title{
THE VARIABILITY OF BX1 DIMBOA BIOSYNTHESIS GENE IN MAIZE INBRED LINES
}

\author{
Sanja Mikić1*, Ankica Kondić-Špika ${ }^{1}$, Ljiljana Brbaklić², Dragana Trkulja ${ }^{1}$, \\ Marina Ćeran ${ }^{1}$, Dušan Stanisavljević ${ }^{1}$, Nada Grahovac ${ }^{1}$
}

\begin{abstract}
Summary
2,4-dihydroxy-7-methoxy-1,4-benzoxazin-3-one (DIMBOA) is a secondary metabolite in plants that renders defence against phytopatogenic bacteria, fungi, insects and other pest organisms. The biosynthesis of DIMBOA is controlled by nine genes, the first $b x 1$ gene governs the transcription of a key enzyme in DIMBOA biosynthesis. The aim of this study was to genotype maize inbred lines used in breeding programmes for the presence of resistant allele in order to identify the source of biotic stress resistance. The variability of $b x l$ gene was assessed in a set of 96 diverse inbred lines with a functional microsatellite marker umc1022 located in $b x 1$ gene. Two marker alleles, the length of 91 and $97 \mathrm{bp}$, were found in the majority of inbred lines, the former being predominant among Lancaster inbred lines and the latter in the BSSS heterotic group. By comparing previous findings on the inbred lines with high level of DIMBOA and resistance with the pedigree information of the maize inbred lines analysed in this study, we postulated that the allele $91 \mathrm{bp}$ could be associate with DIMBOA accumulation and pest resistance. The DIMBOA quantification and evaluation of pest infestations in field trials are needed to verify our results.
\end{abstract}

Keywords: benzoxaziniods, genotyping, maize, microsatellites, resistance

\section{Introduction}

$2,4-$ dihydroxy - 7 - methoxy - 1,4benzoxazin-3-one is a secondary plant metabolite which belongs to benzoxazinoid class of chemical compounds and have a protective role against phytopatogenic bacteria, fungi, insects, nematodes and weeds. It is present in many species of Poaceae family, including maize (Zea mays L.), wheat (Triticum aestivum L.) and rye (Secale cereale L.). In maize, this benzoxazinoid exhibits allelopathic activity and provide resistance against aphids Rhopalosiphum padi L. (Ahmad et al., 2011) and $R$. maidis Fitch (Betsiashvili et al., 2015), corn borers Ostrinia nubilalis Hübner (Cardinal et al., 2006), O. furnacalis Guenée, Sesamia nonagrioides Lef. (Xia et al., 2010), Spodoptera exigua Hübner (Rostás, 2007), Diatraea grandiosella Dyar (Hedin et al., 1994) and fungi Stenocarpella maydis (Berkeley) Sutton (Niemeyer, 1988) and Setosphaeria turcica (Luttrell) Leonard \& Suggs (Ahmad et al., 2011). Toxic DIMBOA aglycone is formed upon plant tissues damage

Original Scientific Paper (Originalni naučni rad)

${ }^{1}$ Mikić S.*, Kondić-Špika A., Trkulja D., Ćeran M., Stanisavljević D., Grahovac N., Institute of Field and Vegetable Crops, Maksima Gorkog 30, Novi Sad, Serbia

${ }^{2}$ Brbaklić Lj., Biogranum Research and Development Center; Toplice Milana 20, Novi Sad, Serbia

*e-mail: sanja.mikic@ifvens.ns.ac.rs 
by interaction of inactive DIMBOA-glucosides stored in vacuoles with specific enzymes, glucosidases, released from plastids (Butrón et al., 2010). The concentration of DIMBOA was showed to decrease as plants mature (Cambier et al., 2000), hence the greatest resistance against pests and diseases in early developmental phases. The biosynthesis of DIMBOA is regulated by nine benzoxazinless (bx) genes (Frey et al., 2009). The bxl gene encodes a key enzyme in DIMBOA biosynthesis (Chomet et al., 2001). Since the polymorphism within $b x l$ was found to have the largest effect of DIMBOA content (Butrón et al., 2010, Cardinal et al., 2006), the dominant allele should provide plants with substantial resistance against biotic stress. The aim of this study was to genotype maize breeding material for $b x 1$ resistant allele in order to identify the source of biotic stress resistance in early developmental stages of maize and examine the possibility of application of the microsatellite in marker assisted selection.

\section{Material and methods}

To assess the presence and variability of bxl gene in maize breeding material, a set of 96 diverse inbred lines developed at the Institute of Field and Vegetable Crops in Novi Sad was screened with a functional microsatellite marker. Twenty six inbred lines were selected from Lancaster heterotic group (LSC), 39 inbred lines belonged to Iowa Stiff Stalk Synthetic (BSSS), 10 lines were from Iodent group, 11 inbreds were adapted from tropical germplasm and was assigned to independent heterotic group, four lines had mixed LSC and independent origin, while the remaining six was developed from crossing BSSS and independent heterotic groups. Extraction of DNA was done from five day-old seedlings using modified CTAB method (Doyle and Doyle, 1990).
The microsatellite marker umc1022 located on the short arm of the chromosome 4 inside of the $B x 1$ gene is used for genotyping the inbred lines. The forward primer was labelled with a fluorescent dye and its sequence was 5'-AACAAGTTTTGTTTGACAAGCCG-3'. The reverse primer was designed based on the sequence 5'-ATGATCACCCCGTCAGCG-3'. The polymerase chain reaction (PCR) mix contained $25 \mathrm{ng}$ of genomic DNA, $0.2 \mathrm{mM}$ dNTP, $1 \times$ Taq buffer with $\mathrm{KCl}, 2 \mathrm{mM} \mathrm{MgCl}_{2}, 1$ $\mathrm{U}$ Taq polymerase and $0.5 \mathrm{pmol}$ of each primer. The PCR was performed under following conditions: DNA denaturation at $94{ }^{\circ} \mathrm{C}$ for 5 min, followed by 38 cycles at $94{ }^{\circ} \mathrm{C}$ for $30 \mathrm{~s}$, annealing at $53^{\circ} \mathrm{C}$ for $45 \mathrm{~s}$, extension at $72{ }^{\circ} \mathrm{C}$ for $45 \mathrm{~s}$ and the final extension for $10 \mathrm{~min}$ at 72 ${ }^{\circ} \mathrm{C}$. The $10 \mu \mathrm{L}$ reaction volume for fragment analysis consisted of $2 \mu \mathrm{L}$ fluorescently labelled PCR products, $0.2 \mu \mathrm{L}$ GeneScan 500 LIZ size standard and 7.8 $\mu \mathrm{L} \mathrm{Hi-Di} \mathrm{formamide.}$ The PCR products were separated by capillary electrophoresis on ABI Prism 3130 and their sizes were determined with Gene Mapper Software Version 4.0 (Applied Biosystems).

\section{Results and discussion}

In total, four alleles of umc1022 marker were detected in the genotyped maize inbred lines. Two out of four alleles were rare alleles with the frequency less than $5 \%$ and were identified in only one genotype each. Null alleles were found in two genotypes. They were manifested by the absence of PCR products, probably due to a mutation at the primer target sites that prevented the attachment of the primer to the DNA template. The remaining two marker alleles that were found in the majority of inbred lines had the PCR amplification products length of 91 and 97 base pairs and were, thus, denoted as $91 \mathrm{bp}$ and $97 \mathrm{bp}$ alleles (Figure 1). 


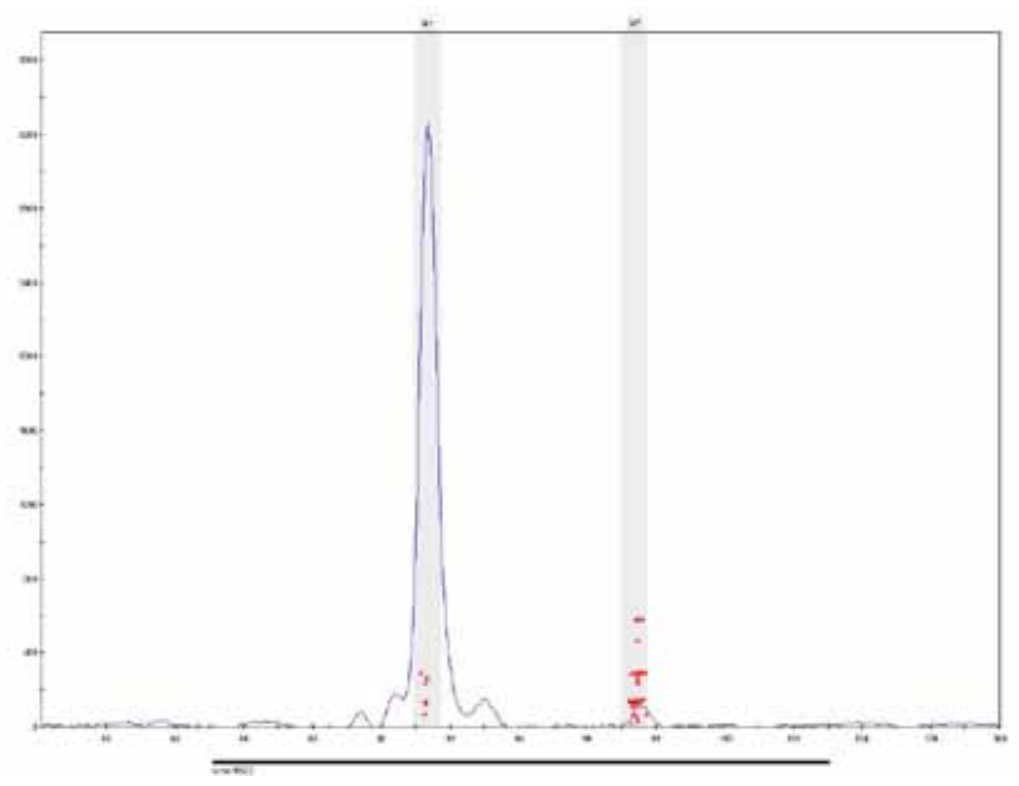

Figure 1. Allele 91 bp of marker umc1022 identified in 20 analyzed maize inbred lines.

Grafikon 1. Alel 91 bp markera umc1022 utvrden kod 20 analiziranih inbred linija kukuruza.



Figure 2. Allele 97 bp of marker umc1022 identified in 72 analyzed maize inbred lines.

Grafikon 2. Alel 97 bp markera umc1022 utvrden kod 72 analiziranih inbred linija kukuruza. 
Twenty inbred lines, comprising $21 \%$ of the all inbred lines, contained $91 \mathrm{bp}$ allele, while 72 lines $(75 \%)$ were characterised by 97 bp allele (Figure 2).

The analysis of the structure of the two groups of inbred lines that were presented with

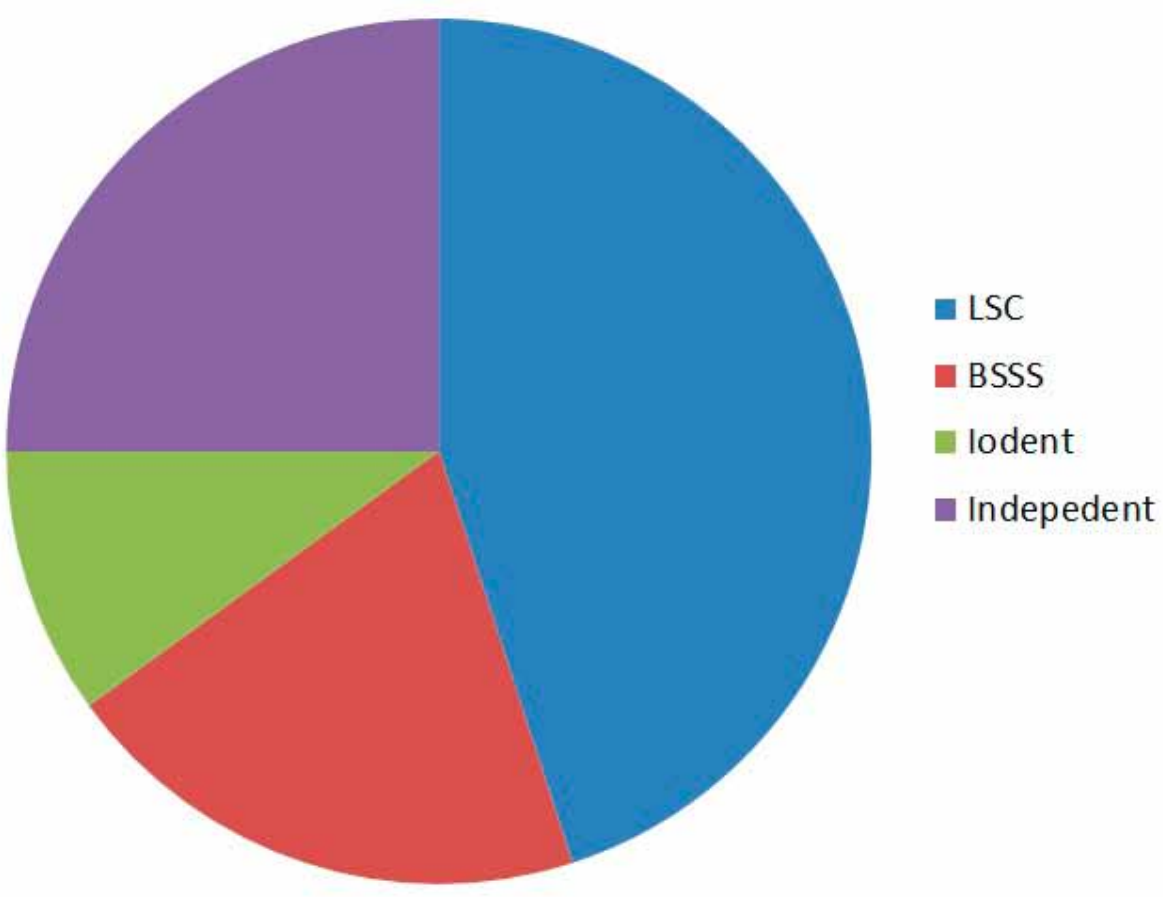

each allele, revealed that among inbreds with $91 \mathrm{bp}$ allele dominated LSC heterotic group (45\%), followed by independent material $(25 \%)$, BSSS $(20 \%)$ and Iodent heterotic group $(10 \%)$ (Figure 3).

Figure 3. The proportion of maize heterotic groups in which was identified 91 bp allele of umc1022 marker in bxl gene

Grafikon 3. Udeo heterotičnih groupa kukuruza kod kojih je utvrden alel 91 bp markera umc1022 u bx1 genu.

In the group of inbred lines with $97 \mathrm{bp}$ allele, BSSS lines constituted the majority with $47 \%$, succeeded by LSC (24\%), independent material $(8 \%)$, inbreds developed from mixed
BSSS and independent groups (8\%), Iodent heterotic group (7\%) and inbred lines with mixed origin of LSC and independent groups $(6 \%)$ (Figure 4). 


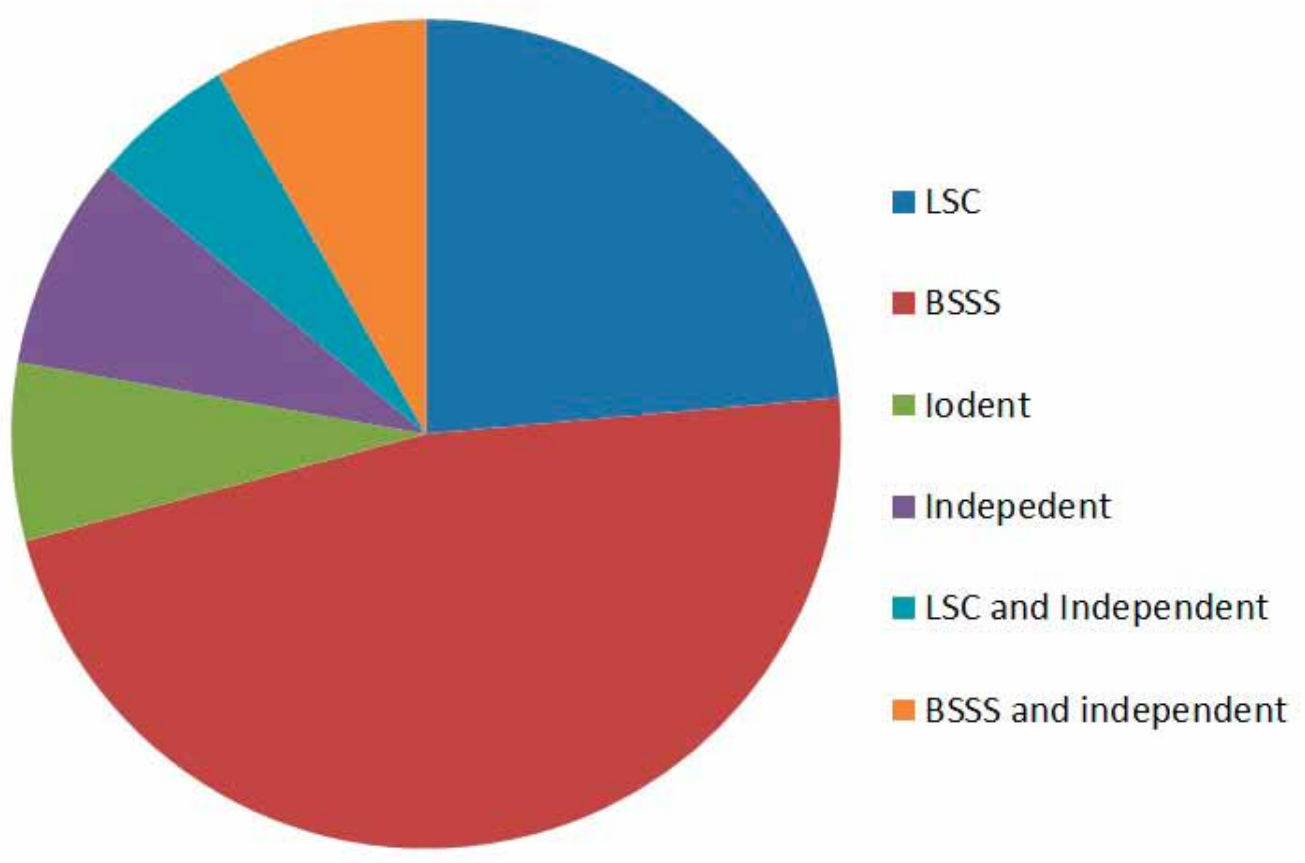

Figure 4. The proportion of maize heterotic groups in which was identified 97 bp allele of umc1022 marker in bx1 gene

Grafikon 4. Udeo heterotičnih groupa kukuruza kod kojih je utvrđen alel 97 bp markera umc1022 u bx1 genu.

A considerable fraction of LSC lines that gathered in the first group may be because a number of the analysed LSC inbred lines were developed by reselection of Mo17 and had a portion of Mo17 in their pedigrees. This may be also true for BSSS line B73 and the inbreds with similar genetic background that formed the other group.

Several maize inbred lines were previously reported to have high level of DIMBOA content and to harbour resistance to maize pests. B97 inbred line developed from Iowa Corn Borer Synthetic population showed to be resistant to European corn borer (Ostrinia nubilalis Hüber) (Abel et al., 2000). This inbred line, together with Mo17 and M37W, possess aphid resistance and high DIMBOA concentration even in later developmental stages (Zheng et al., 2015). This finding is in line with the study of Betsiashvili et al. (2015) with near-isogenic lines revealing that increased DIMBOA accumulation is positively associated with Mo17 allele, contrarily to the B73 allele. The inbred lines H99 (Cardinal et al., 2006), B49 and CI31A (Klenke et al., 1987) were also found to be resistant to the first generation of European corn borer and contain high levels of DIMBOA. 
Among the maize inbred lines analysed in this study, Mo17, B97, H99 and the inbreds that have different proportions of these three lines in their pedigrees all contained $91 \mathrm{bp}$ allele of $b x 1$ gene. On the other hand, the line B73, previously characterised with low DIMBOA content (Betsiashvili et al., 2015), and lines reselected from it, had $97 \mathrm{bp}$ allele. On these premises, it could be assumed that allele $91 \mathrm{bp}$ may affect high DIMBOA biosynthesis and confer resistance, whereas $97 \mathrm{bp}$ allele may be linked to low DIMBOA accumulation and susceptibility to biotic stress. Before applying regular germplasm screenings for resistance in maize breeding programmes with umc1022 marker, this assumption should be verified in further studies including measuring DIMBOA concentration and field trials for evaluation of pest resistance.

\section{Conclusion}

The natural occurring plant biochemical, DIMBOA, has an untapped potential to be used in breeding to alleviate biotic stress. A fast and simple method for identification of genotypes with high DIMBOA content that can be exploited as a source of resistance is essential for successful breeding programmes. Owing to complete linkage between $u m c 1022$ and the $b x 1$ gene, the marker can be applied directly in the maize selection process. Prior verification of the marker alleles linked to resistance and DIMBOA biosynthesis, however, is required for the ushering umc1022 in the routine marker assisted selection.

\section{Acknowledgement}

This research was funded by the Serbian Ministry of Education, Science and Technological Development under the project TR31073.

\section{References}

Abel CA, Berhow MA, Wilson RL, Binder BF, Hibbard BE (2000): Evaluation of conventional resistance to European corn borer (Lepidoptera: Crambidae) and western corn rootworm (Coleoptera: Chrysomelidae) in experimental maize lines developed from a backcross breeding program. J. Econ. Entomol., 93: 1814-1821.

Ahmad S, Veyrat N, Gordon-Weeks R, Zhang Y, Martin J, Smart L, Glauser G, Erb M, Flors V, Frey M, Ton J. (2011): Benzoxazinoid Metabolites Regulate Innate Immunity against Aphids and Fungi in Maize. Plant Physiol., 157: 317-327.

Betsiashvili M, Ahern KR, Jander G (2015): Additive effects of two quantitative trait loci that confer Rhopalosiphum maidis (corn leaf aphid) resistance in maize inbred line Mo17. J. Exp. Bot., 66: 571578.

Butrón A, Chen YC, Rottinghaus GE, McMullen MD (2010): Genetic variation at bx1 controls DIMBOA content in maize. Theor. Appl. Genet., 120: 721-734.

Cardinal AJ, Lee M, Guthrie WD, Bing J, Austin DF, Veldboom LR, Senior ML (2006): Mapping of factors for resistance to leaf-blade feeding by European corn borer (Ostrinia nubilalis) in maize. Maydica, 51: 93-102.

Cambier V, Hance T, De Hoffmann E (2000): Variation of DIMBOA and related compounds content in relation to the age and plant organ in maize. Phytochem., 53: 223-229.

Chomet PS, Frey M, Gierl A, inventors; Dekalb Genetics Corporation, assignee. (2001): Maize DIMBOA biosynthesis genes. 
United States patent US 6,331,660. 2001 Dec 18.

Doyle JJ, Doyle JL (1990): Isolation of plant DNA from fresh tissue. Focus, 12:1315.

Frey M, Schullehner K, Dick R, Fiesselmann A, Gierl A (2009): Benzoxazinoid biosynthesis, a model for evolution of secondary metabolic pathways in plants. Phytochem., 70: 1645-51.

Hedin PA, Davis FM, Williams WP (1993): 2-Hydroxy-4, 7-dimethoxy-1, 4-benzoxazin-3-one (NO-MeDIMBOA), a possible toxic factor in corn to the southwestern corn borer. J. Chem. Ecol., 19: 531-42.

Klenke JR, Russell WA, Guthrie WD, Martinson CA, Pedersen WL (1987): Disease resistance in five cycles of BS9 corn synthetic selected for resistance to two generations of European corn borer. Phytopathol., 7: 735-739.
Niemeyer HM (1988): Hydroxamic acids (4-hydroxy-1,4-benzoxazin-3-ones), defense chemicals in the Gramineae. Phytochem., 27: 3349-3358.

Rostás M (2007): The effects of 2,4-dihydroxy7-methoxy-1,4-benzoxazin-3-one on two species of Spodoptera and the growth of Setosphaeria turcica in vitro. J. Pest Sci., 80: 35-41.

Xia L, He KL, Wang ZY, Bai SX (2010): Quantitative trait loci for Asian corn borer resistance in maize population Mc37 x Zi330. Agric. Sci. China, 9: 7784.

Zheng L, McMullen MD, Bauer E, Schön CC, Gierl A, Frey M (2015): Prolonged expression of the BX1 signature enzyme is associated with a recombination hotspot in the benzoxazinoid gene cluster in Zea mays. J. Exp. Bot., 66: 3917-3930. 


\title{
VARIJABILNOST BX1 GENA ZA BIOSINTEZU DIMBOA-E U INBRED LINIJAMA KUKURUZA
}

\author{
Sanja Mikić, Ankica Kondić-Špika, Ljiljana Brbaklić, Dragana Trkulja, \\ Marina Ćeran, Dušan Stanisavljević, Nada Grahovac
}

\section{Izvod}

2,4-dihydroxy-7-methoxy-1,4-benzoxazin-3-one (DIMBOA) je sekundarni metabolit koji omogućava biljkama zaštitu od fitopatogenih bakterija, gljiva, insekata i drugih štetnih organizama. Biosintezu DIMBOA-e regulišu devet gena, od kojih prvi $b x l$ upravlja transkripcijom ključnog enzima u biosintezi DIMBOA-e. Cilj ovog rada bio je da se među inbred linijama kukuruza iz oplemenjivačkog programa utvrdi prisustvo otpornog alela $b x l$ gena kako bi se identifikovali izvori otpornosti na biotički stres. Varijabilnost gena $b x l$ je ocenjena kod 96 genetički divergentnih inbred linija pomoću funkcionalnog mikrosatelitskog markera umc1022 koji se nalazi u genu bxl. Dva alela markera, dužine 91 bp i 97 bp, ustanovljeni su kod većine inbred linija, prvi alel je bio zastupljeniji među Lancaster linijama, dok je drugi alel bio frekventniji u BSSS heterotičnoj grupi. U inbred linijama kod kojih je utvrđen alel 91 bp (Mo17, B97 i H99) u prethodnih istraživanjima je određen visok nivo DIMBOA-e i otpornost prema štetočinama. Shodno tome, pretpostavljamo da je alel 91 bp u vezi sa nakupljanjem DIMBOA-e i sa otpornošću prema biotičkom stresu. Kvantifikacija DIMBOA-e i ocena štete od insekata u poljskim ogledima potrebna je da bi se potvrdili izneti rezultati.

Ključne reči: benzoksazinoidi, genotipizacija, kukuruz, mikrosateliti, otpornost

Primljen: 19.07.2016. Prihvaćen: 3.10.2016. 